https://doi.org/10.46813/2020-130-174

\title{
PLASMA-SURFACE INTERACTION OF ELECTRIC ARC DISCHARGE BETWEEN COMPOSITE Cu-Cr ELECTRODES
}

\author{
A. Murmantsev ${ }^{1}$, A. Veklich ${ }^{1}$, V. Boretskij ${ }^{1}$, M. Bartlová ${ }^{2}$ L. Dostál', J. Píška ${ }^{2}$, D. Šimek ${ }^{2}$, \\ A. Gajdos ${ }^{2}$, A. Tolochyn ${ }^{3}$ \\ ${ }^{1}$ Taras Shevchenko National University of Kyiv, Kyiv, Ukraine; \\ ${ }^{2}$ Brno University of Technology, Brno, Czech Republic; \\ ${ }^{3}$ Frantsevich Institute for Problems of Materials Science NAS of Ukraine, Kyiv, Ukraine \\ E-mail: murmantsev.aleksandr@gmail.com
}

In this work the plasma of electric arc discharges between $\mathrm{Cu}-\mathrm{Cr}$ composite electrodes, which material were pressured and sintered at different temperatures 750 or $1050^{\circ} \mathrm{C}$, are investigated by Optical Emission Spectroscopy (OES). The Scanning Electron Microscopy (SEM) with Energy-Dispersive X-ray Spectroscopy (EDXS) are used to study the working surface of electrodes, modified by thermal effect of breaking electrical arc in the air atmosphere. The erosion intensity of electrodes' material due to plasma-surface interaction is estimated in indirect way by determination of metal vapours content in the discharge gap in an assumption of local thermodynamic equilibrium (LTE). The plasma composition is calculated in this case on the base of experimentally determined plasma parameters: temperature and electron density.

PACS: 52.70.-m, 52.80.Mg

\section{INTRODUCTION}

Nowadays, the issue of developing new composite materials, improving the characteristics of existing ones and optimizing their manufacturing technologies are still relevant due to continuous development of most branches of electric power industry. The composites materials on the base of copper and chromium mixture, where perfect electrical and thermal conductivity of copper as well as refractoriness of chromium play a predominated role in the resistance to thermal effect of electric arc discharge plasma, which occurs during contact switching, are particular interest.

The $\mathrm{Cu}-\mathrm{Cr}$ composites have long been used as the electrodes' materials in vacuum arc quenching chambers of middle/high power [1] and in various devices of electrical discharge machining [2,3].

It is well-known, that a lot of different technologies of manufacturing of such composite materials (e.g. powder metallurgy) are developed as well as a large number of different variations of its component ratio are proposed. Each of these factors can significantly influence the output characteristics of fabricated composites.

It was found in the work of Rieder et al. [4], that contact resistance of composite $\mathrm{Cu} 75-\mathrm{Cr} 25$ electrodes, as expected, is lower in comparison with $\mathrm{Cu} 50-\mathrm{Cr} 50$. In addition, the authors emphasized that the erosion of the contacts increases slightly when initial metal powders with smaller particle size are used in the production.

Fundamentally other studies are presented in the work of Lahiri et al. [5], which are devoted to the comparison of various technologies for the fabrication of $\mathrm{Cu}-\mathrm{Cr}$ composites. It was found in a result of study, that the explosive compaction of mechanically alloyed $\mathrm{Cu}-\mathrm{Cr}$ powder followed by solid-state sintering or coating of mechanical powder with $\mathrm{Cu}$ followed byuniaxial cold compaction and solid-state sintering could be a better option for production of electrical contact materials.
The solid-state sintering technology was investigated by Papillon et al. [6] as well. The authors founded that chromium as a component of the composite material has good heterogeneous properties that allow it to attach volatile compounds formed from surface oxides, which in turn prevents swelling of the material pores.

As it can be concluded from aforementioned, the composite $\mathrm{Cu}-\mathrm{Cr}$ material characteristics are strongly depend on many factors, each of which requires careful research with the aim of optimization of manufacturing technologies.

Thus, $\mathrm{Cu}-\mathrm{Cr}$ contact materials, manufactured by sintering technology, are characterized by a small residual porosity, which can significantly affect the electrical and thermal properties, which in turn can significantly affect the erosion behavior of the electrodes. The porosity of the material can be reduced by increasing the temperature, at which the composite materials are sintered.

This parameter, namely sintering temperature, of such composite material production is not enough studied, which can affect the output material characteristics.

It can be noted, that such composite electrodes, fabricated at a sintering temperature of $750^{\circ} \mathrm{C}$, have already been investigated in our previous work [7]. But the effect of the sintering temperature, at which the electrodes are manufactured, remained outside the frame of mentioned study.

Thus, the aims of this work are the investigation and qualitatively comparison of composite $\mathrm{Cu}-\mathrm{Cr}$ electrodes manufactured at sintering temperatures of 750 and $1050^{\circ} \mathrm{C}$. Such kind of comparison is carried out by estimation of metal vapour content in discharge gap originated due to the interaction between electrode surface and thermal plasma of the electric arc discharge. Namely, OESis used to study the thermal plasma parameters of arc discharge between $\mathrm{Cu}-\mathrm{Cr}$ composite electrodes as well as SEM with EDXS isapplied to ISSN 1562-6016. BAHT. 2020. №6(130) 
study the modified working surface of such electrodes. In particular, plasma temperature was determined by Boltzmann plot technique in assumption of Local Thermodynamic Equilibrium (LTE) and electron density is determined from the Full Width on Half Maximum (FWHM) of copper spectral. The abovementioned metal vapour content is calculated on the base of these plasma parameters in LTE assumption as well.

\section{EXPERIMENT}

The breaking arc discharges in the air atmosphere at current of $120 \mathrm{~A}$ were as the object of research in this work. The scheme of the experimental setup is shown in Fig. 1.



Fig. 1. Scheme of experimental device

The arc was ignited between the upper fixed cathode and the lower anode, which is connected to the pneumatic drive. The registration of plasma emission spectra, started after the operation of the last one, was performed using a Newton 940 spectrometer in the high-speed mode (1000 frames/s) in the spectral range from 400 to $600 \mathrm{~nm}$. Calibration of the spectral device sensitivity was performed using a deuterium lamp.

\section{RESULTS AND DISCUSSIONS}

In Fig. 2 the temporal evolutions of plasma emission spectra of arc discharge between $\mathrm{Cu}-\mathrm{Cr}$ composite electrodes, compressed at a sintering temperature of 750 and $1050{ }^{\circ} \mathrm{C}$, are shown respectively.

The clearly observed atomic spectral lines of $\mathrm{Cu} \mathrm{I}$ $465.1,510.5,515.3,521.8$, and $529.2 \mathrm{~nm}$ were used to determine the plasma temperature by the Boltzmann plot technique.

Each above-mentioned line during temporal evolution was approximated by the Voigt function with account of the contribution of the spectrometer instrumental function to the width of the spectral line. It was assumed that the spectral line broadening by Doppler effect is negligible in such discharge conditions. Chromium spectral lines were not used in this work due to the impossibility of separating the $\mathrm{Cr} \mathrm{I}$ spectral lines profiles in the appropriate manner.
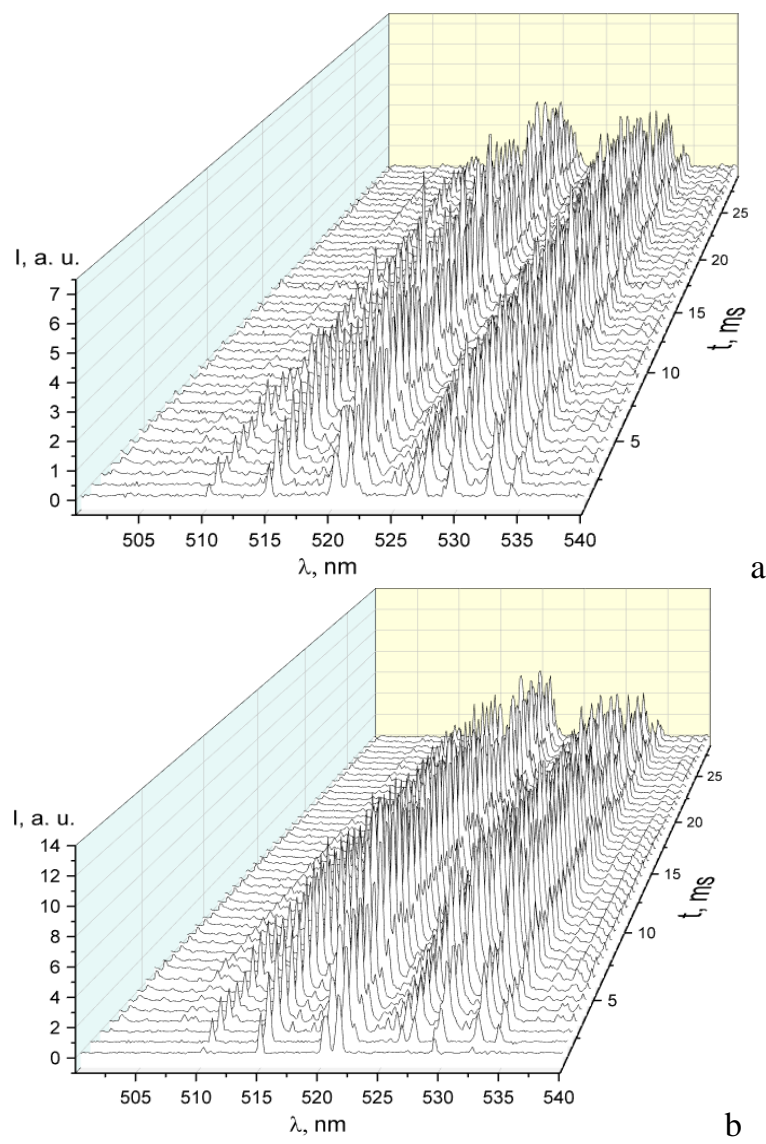

a

Fig. 2. Temporal evolution of plasma emission spectra of electric arc discharge between $\mathrm{Cu}$-Cr composite electrodes pressured and sintered at temperature: $a-750$ and $b-1050{ }^{\circ} \mathrm{C}$

It should be noted, that the spectral lines $\mathrm{Cu}$ I 570.0 and $578.2 \mathrm{~nm}$, traditionally, are also can be used in Boltzmann plot technique [8]. But, as it turned out, both of these spectral lines can not be perfectly resoluted due to the presence of chromium spectral lines with close wavelengths. Therefore, the $\mathrm{Cu}$ I 570.0 and $578.2 \mathrm{~nm}$ lines were not included in the determination of plasma temperature within frame of this work. The spectroscopic data, used in Boltzmann plots, were clearly selected in previous study [8].

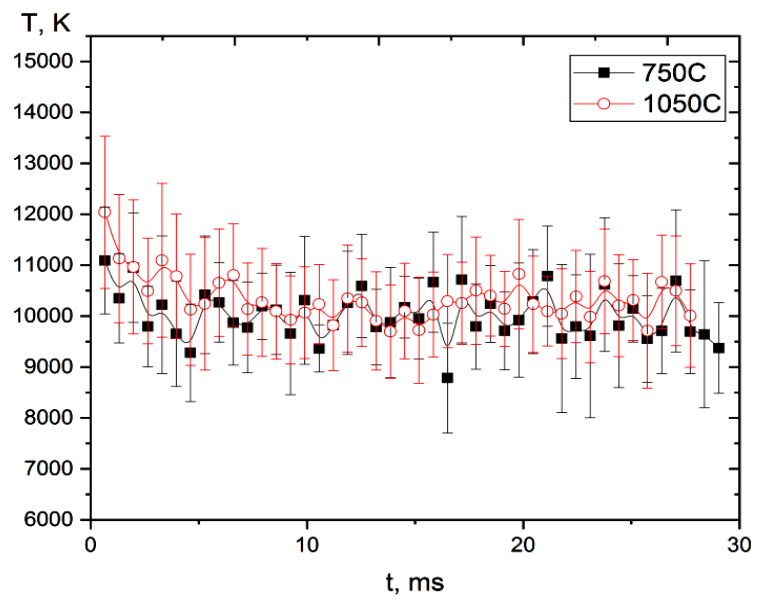

Fig. 3. Temporal evolution of plasma temperature of arc discharge between $\mathrm{Cu}$-Cr composite electrodes pressured at sintering temperature 750 and $1050^{\circ} \mathrm{C}$ 


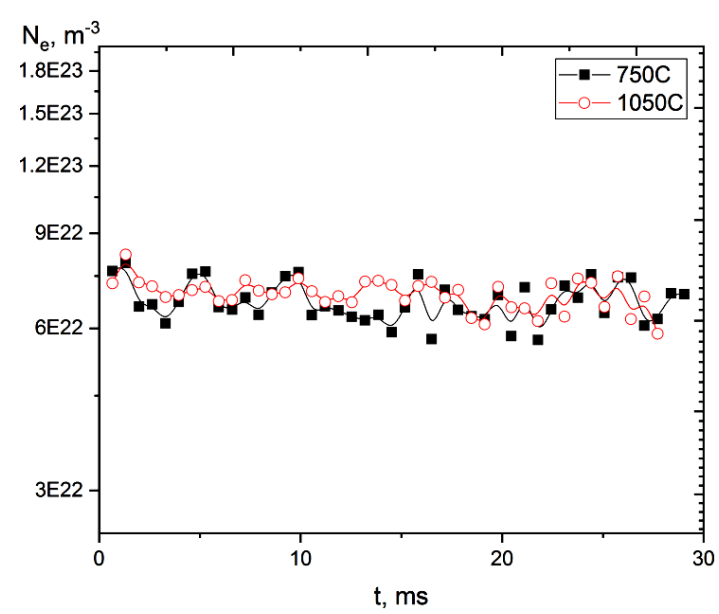

Fig. 4. Temporal evolution of electron density in discharge plasma between $\mathrm{Cu}-\mathrm{Cr}$ composite electrodes pressured at sintering temperature 750 and $1050^{\circ} \mathrm{C}$


Fig. 5. Temporal evolution of metal vapour contents and current in the electric discharge plasma between $\mathrm{Cu}-\mathrm{Cr}$ composite electrodes pressured and sintered at temperature: $a-750$ and $b-1050{ }^{\circ} \mathrm{C}$

The obtained temporal evolution of spectral lines intensities are used to determine the temperature behaviours by Boltzmann plot technique during discharge operation.

The electron densities' behavior is obtained from the temporal evolutions of the $\mathrm{Cu}$ I $515.3 \mathrm{~nm}$ spectral line FWHM in assumption that the quadratic Stark effect is the dominant mechanism of this line broadening [9].
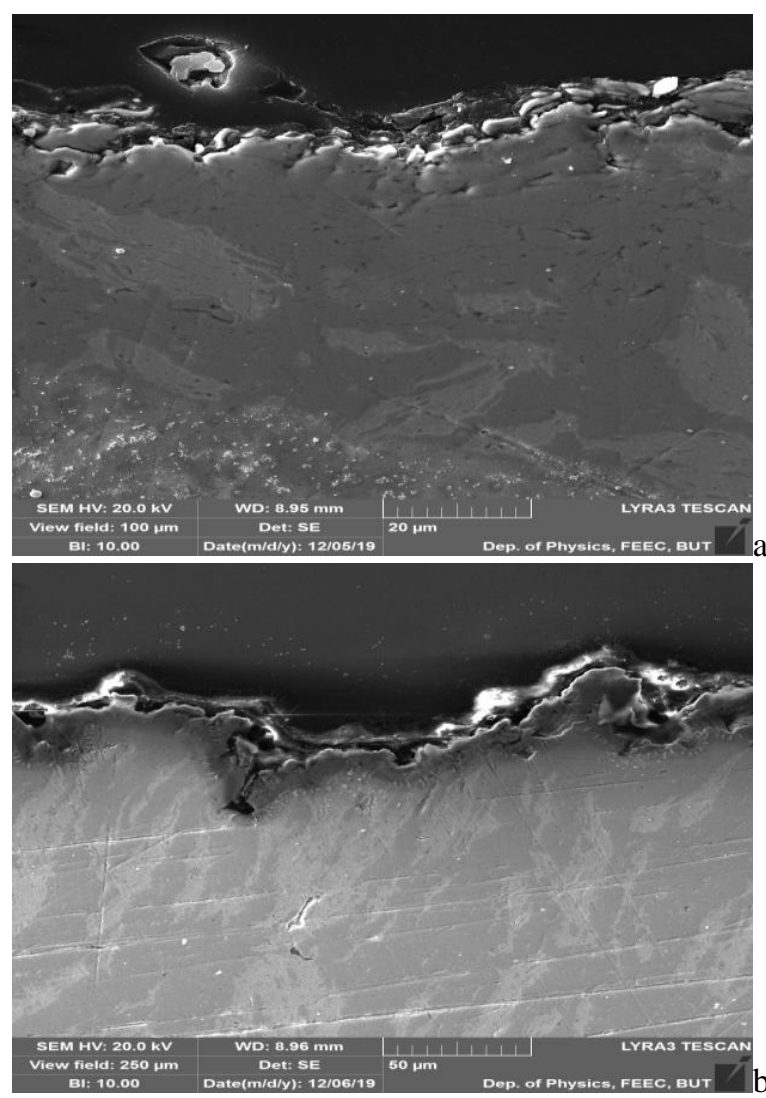

Fig. 6. Images of non-modified cathode surfaces (electrode materials, pressured and sintered at temperature: $a-750$ and $b-1050{ }^{\circ} \mathrm{C}$ )

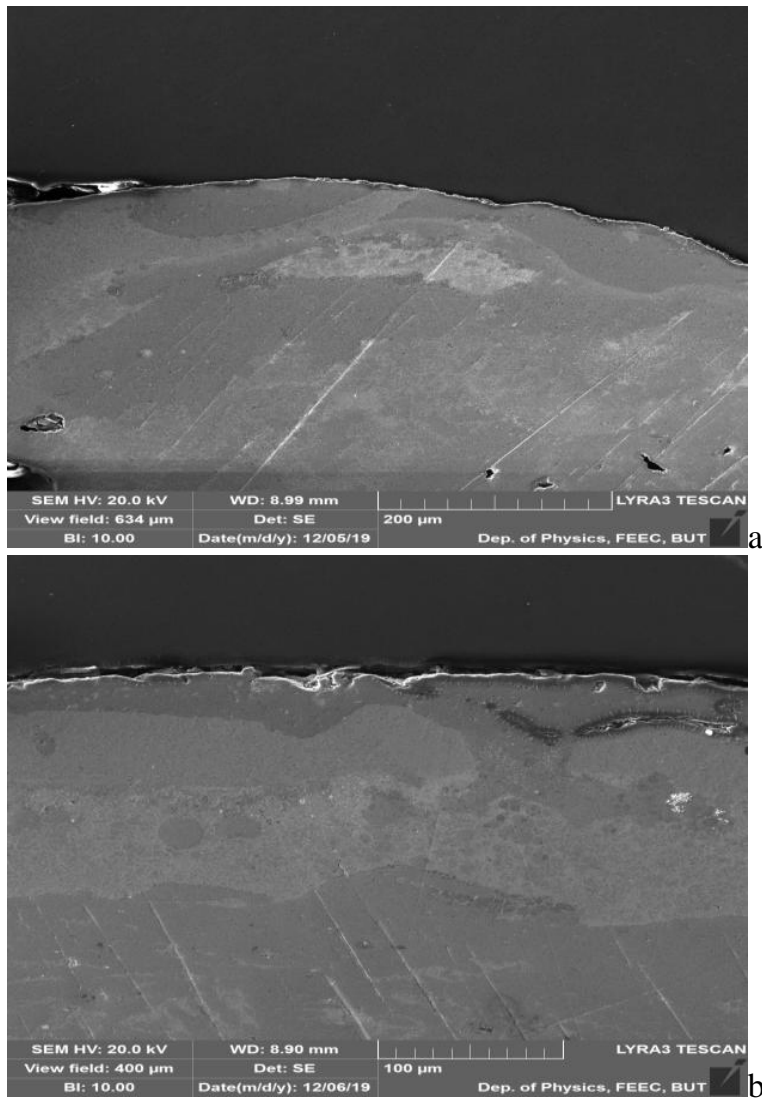

Fig. 7. Images of modified cathode surfaces (electrode materials, pressured and sintered at temperature:

$a-750$ and $b-1050^{\circ} \mathrm{C}$ ) 
The temporal evolutions of the temperatures and electron densities in the plasma of electric arc discharges between composite $\mathrm{Cu}-\mathrm{Cr}$ electrodes, pressured at different sintering temperatures, are shown in Figs. 3, 4, respectively. As one can see, both parameters coincide within the measurement uncertainty.
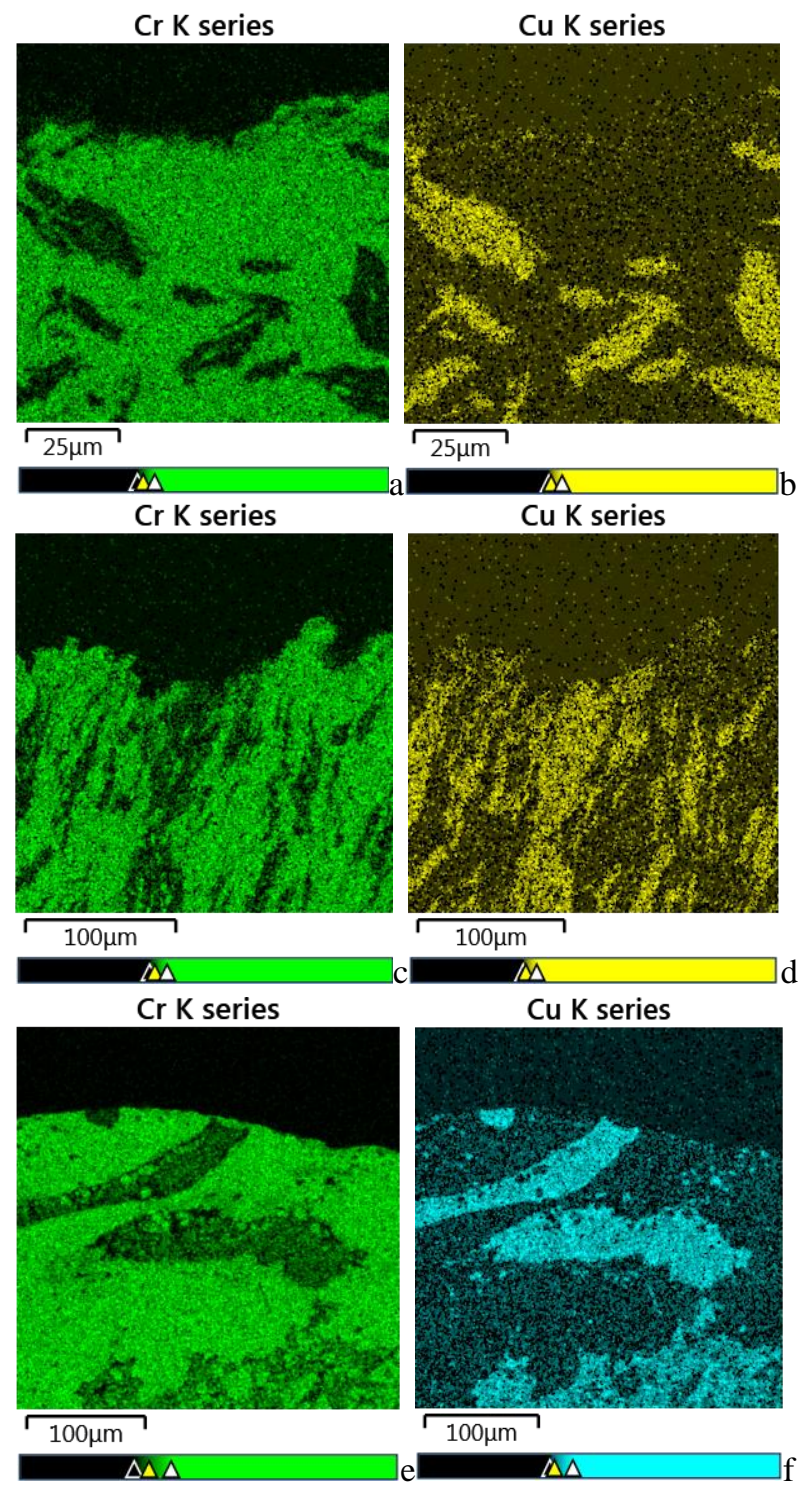

Cr K series



$\longdiv { 1 0 0 \mu \mathrm { m } }$



Fig. 8. Elemental mapping of non-modified cathode surfaces ( $a, b, c$, and d) and modified cathode surfaces

$(e, f, g$ and $h)$ (electrode materials, pressured and sintered at temperature $750(a, b, e$, and $f)$ and $1050^{\circ} \mathrm{C}(c, d, g$, and $\left.h)\right)$
The presented plasma parameters are used as the input data of the equations system for calculation of the plasma equilibrium composition. The algorithm of this calculation is presented in [7].

The metal vapour contents in the discharge plasma between both types of electrodes, calculated in such way, are shown in Fig. 5, respectively. Some oscillations of such contents can be explained by according character of current oscillation.

It may indicate the identical behaviour of the both electrodes material under the influence of thermal plasma of electric arc discharge at current $120 \mathrm{~A}$. These results are not in agreement with our previous, obtained at 3.5 $\mathrm{A}$ [10], which showed that electrodes, pressured and sintered at temperature $1050^{\circ} \mathrm{C}$, have better erosion resistance. On the other hand, it must be stressed, that the spatial resolution was not provided within this study.

To more detail clarify the plasma-surface interaction the SEM with EDXS is used. In Figs. 6, 8,a-d the nonmodified cathode surfaces of both electrodes types are shown. The modified cathode surfaces by thermal effect of electric arc discharge plasma are shown in Figs. 7, 8 ,e-h. It is clearly observed, that the surface of both different cathodes are significantly change. Specifically, the copper, as a non-refractory component of composite electrodes (bright areas), melts inside the electrode and accumulates at the working surface layer. Taking into account the dimensions of these areas, we can conclude concerning the degree of arc discharge plasma impact on the electrodes.

As one can see, the electrodes areas, in which copper has melted, does not exceed $200 \mu \mathrm{m}$ for both $\mathrm{Cu}-\mathrm{Cr}$ composite electrodes. Consequently, the results of SEM of the electrodes surface confirm the conclusions of the OES that the plasma-surface interaction consequences of electric arc discharge between composite $\mathrm{Cu}-\mathrm{Cr}$ electrodes, pressured at different temperatures, are the same.

\section{CONCLUSIONS}

The plasma-surface interaction of electric arc discharges between two types of composite $\mathrm{Cu}-\mathrm{Cr}$ electrodes, manufactured at the sintering temperatures of 750 or $1050^{\circ} \mathrm{C}$, are investigated. Namely, the temporal evolutions of metal vapour contents were calculated on the base of experimentally determined by OES plasma parameters (temperature and electron density). Additionally, the SEM with EDXS was applied to investigate the surfaces of electrodes modified by the thermal effect of electric arc discharge plasma.

It was found, that the influence of thermal effect of electric arc discharge plasma is the same between composite $\mathrm{Cu}-\mathrm{Cr}$ electrodes, manufactured at different sintering temperatures. It may indicate the identical behaviour of the both electrodes material under the influence of thermal plasma of electric arc discharge at current $120 \mathrm{~A}$. These results are not in agreement with those, obtained at 3.5 A, which showed that electrodes, pressured and sintered at temperature $1050{ }^{\circ} \mathrm{C}$, have better erosion resistance.

The results of SEM of the electrodes surface confirm the conclusions of the OES that the plasma-surface 
interaction, consequences of electric arc dischargebetween composite $\mathrm{Cu}-\mathrm{Cr}$ electrodes, pressured at different sintering temperatures are the same for both electrodes types.

\section{ACKNOWLEDGEMENT}

This work was supported under joint project of research and technology collaboration No.8J19UA038 between Ukraine (No.M/1-2020) and Czech Republic (No.7AMB197UA).

\section{REFERENCES}

1. P.G. Slade. Electrical contacts, principles and applications. CRC Press, 2014.

2. O. Gülcan, İ. Uslan,Y. Usta, C. Çoğun. Performance and surface alloying characteristics of $\mathrm{Cu}-\mathrm{Cr}$ and $\mathrm{Cu}-$ Mo powder metal tool electrodes in electrical discharge machining // Machining Science and Technology. 2016, p. 523-546.

3. C. Mingrang, H. Yuefeng, C. Yilong, Y. Shengqiang. Mechanism and Experimental Research on Small-Hole EDM with $\mathrm{Cu}-\mathrm{Cr}$ Composite //Electrode. Sensors and Transducers. 2014, v.174, p. 268-272.

4 W.F. Rieder, M. Schussek, W. Glatzle, E. Kny. The Influence of Composition and $\mathrm{Cr}$ Particle Size of $\mathrm{Cu} / \mathrm{Cr}$ Contacts on Chopping Current, Contact Resistance, and Breakdown Voltage in Vacuum Interrupters // IEEE
Transactions on components, hybrids, and manufacturing technology. 1989, v. 12 (2), p. 273-283. 5. I. Lahiri, S. Bhargava. Compaction and sintering response of mechanically alloyed $\mathrm{Cu}-\mathrm{Cr}$ powder // Powder Technology. 2009, v. 189, p. 433-438.

6. A. Papillon, J. Missiaen, J. Chaix, S. Roure, H. Schellekens. Sintering mechanisms of $\mathrm{Cu}-\mathrm{Cr}$ metallic composites //Int. Journal of Refractory Metals and Hard Materials.2016, v. 65, p. 9-13.

7. A. Veklich, V. Boretskij, M. Kleshych, S. Fesenko, A. Murmantsev, A. Ivanisik, O. Khomenko, O. Tolochyn, M. Bartlova. Thermal plasma of electric arc discharge between $\mathrm{Cu}-\mathrm{Cr}$ composite electrodes // 23rd Symposium on Physics of Switching Arc. 2019, v. 6(1), p. 27-30. doi:10.14311/ppt.2019.1.27.

8. I.L. Babich, V.F. Boretskij, A.N. Veklich, R.V. Semenyshyn. Spectroscopic data and Stark Broadening of $\mathrm{Cu}$ I and $\mathrm{Ag}$ I spectral lines: selection and analysis // Advances in Space Research. 2014, v. 54, p. 1254-1263.

9. R. Konjevic, N. Konjevic. Stark broadening and shift of neutral copper spectral lines // Fizika. 1986, v. 18(4), p. 327-335 (in Russian).

10. A. Veklich, M. Kleshych, A. Murmantsev, S. Fesenko, V. Boretskij, O. Tolochyn. Spectroscopy of Thermal Plasma of Electric Arc Discharge between Consumable $\mathrm{Cu}-\mathrm{Cr}$ Composite Electrodes // XV Conference of Electronics and Applied Physics. 2019, p. 87-89.

Article received 25.10 .2020

\section{ВЗАИМОДЕЙСТВИЕ ПЛАЗМА-ПОВЕРХНОСТЬ В ЭЛЕКТРОДУГОВЫХ РАЗРЯДАХ МЕЖДУ КОМПОЗИТНЫМИ Сu-Сr-ЭЛЕКТРОДАМИ}

\section{А. Мурманцев, А. Веклич, В. Борецкий, М. Бартлова, Л. Достал, Дюс. Пишка, Д. Шимек, А. Гайдос,}

А. Толочин

Методами оптической эмиссионной спектроскопии (ОЭС) исследуется плазма электродуговых разрядов между композитными $\mathrm{Cu}-\mathrm{Cr}$-электродами, материал которых в процессе изготовления подвергался прессованию и спеканию при разных температурах: 750 или $1050{ }^{\circ} \mathrm{C}$. Для изучения рабочей поверхности электродов, подвергающейся термическому воздействию разрывной электрической дуги в атмосфере воздуха, использована сканирующая электронная микроскопия (СЭМ), дополненная энергодисперсионной рентгеновской спектроскопией (ЭДРС). Интенсивность эрозии материала электродов вследствие взаимодействия плазма-поверхность оценивалась косвенным методом путем определения содержания паров металлов в разрядном промежутке в предположении локального термодинамического равновесия (ЛТР). Состав плазмы в этом случае рассчитан из экспериментально полученных параметров: температуры и электронной концентрации.

\section{ВЗАЕМОДІЯ ПЛАЗМА-ПОВЕРХНЯ В ЕЛЕКТРОДУГОВИХ РОЗРЯДАХ МІЖ КОМПОЗИТНИМИ Сu-Сr-ЕЛЕКТРОДАМИ}

\section{О. Мурманцев, А. Веклич, В. Борецький, М. Бартлова, Л. Достал, Дюс. Пішка, Д. Шимек, А. Гайдос, О. Толочин}

Методами оптичної емісійної спектроскопії досліджується плазма електродугових розрядів між композитними $\mathrm{Cu}-\mathrm{Cr}$-електродами, матеріал яких у процесі виготовлення піддавався пресуванню та спіканню при різних температурах: 750 або $1050^{\circ} \mathrm{C}$. Для дослідження робочої поверхні електродів, які зазнали впливу термічної дії розривної електричної дуги в атмосфері повітря, використовується скануюча електронна мікроскопія (CEM), доповнена енергодисперсійною рентгенівською спектроскопією (ЕДРС). Інтенсивність ерозії матеріалу електродів внаслідок взаємодії плазма-поверхня оцінювалась у непрямий спосіб шляхом визначення вмісту парів металів у розрядному проміжку в припущенні локальної термодинамічної рівноваги (ЛТР). Склад плазми в даному випадку розрахований з експериментально отриманих параметрів плазми: температури та електронної концентрації. 